\title{
Regional Anesthesia for Cesarean Section in Obese Pregnant Women: A Retrospective Study
}

\author{
Flávia Romano Rodrigues ${ }^{1}$, Maria José Nascimento Brandão ${ }^{2}$
}

\begin{abstract}
Summary: Rodrigues FR, Brandão MJN - Regional Anesthesia for Cesarean Section in Obese Pregnant Women: A Retrospective Study.
Background and objectives: The objective of the data gathering was to indentify anesthetic techniques, and their difficulties and complications in patients with $\mathrm{BMI} \geq 30 \mathrm{~kg} \cdot \mathrm{m}^{-2}$ undergoing cesarean sections. The study intends to support the development of new protocols and more adequate conducts for this population of pregnant women.
\end{abstract}

Methods: This is a retrospective study of data and anesthetic complications in obese patients older than 18 years of age who underwent cesarean sections from January 2004 to December 2006; variables investigated included: age, weight, height, BMI, physical status (ASA), anesthetic techniques, difficulties in palpation and puncturing, hemodynamic complications (bleeding and hypotension), and anesthetic complications.

Results: Three hundred and fifteen anesthetic forms were evaluated. Mean age was 29.1 years, mean BMI 39.25, and the majority of patients was classified as ASA II (63.2\%). Spinal anesthesia charts used more often, difficulty to puncture was reported in 47 procedures, and difficulty to palpate was reported in 31 procedures.

Conclusions: Technical difficulties as well as hypotension, bleeding, and surgical time were more frequent in patients with higher degrees of obesity.

Keywords: Pregnancy, High-risk; Obesity, Morbid; Anesthesia, Spinal; Anesthesia, Epidural; Cesarean Section; Anesthesia Obstetrical.

[Rev Bras Anestesiol 2011;61(1): 13-20] @Elsevier Editora Ltda.

\section{INTRODUCTION}

The World Health Organization characterizes obesity as a pandemic whose prevalence is higher in women, classifying it based on the association of Body Mass Index (BMI) and comorbidities (Table I) ${ }^{1}$. Maternal morbidity associated to obesity is increasing, especially due to hypertension (prior or gestational) ${ }^{2}$, diabetes mellitus (prior or gestational), respiratory disorders (asthma and sleep apnea), thromboembolic diseases, cardiomyopathies ${ }^{3}$, higher incidence of cesarean sections, and higher number of infections (especially urinary tract, surgical wound infections and endometritis) ${ }^{4,5}$. A study conducted in Brazil at the end of the last century reported a prevalence of $5.5 \%$ of obesity in pregnant women ${ }^{6}$. Physiological changes of pregnancy associated to those of obesity mean that pregnant women have limited physiological reserves, which are proportional to the degree and duration of obesity. The objective of this study was to identify anesthetic techniques and their difficulties and complications in patients with $\mathrm{BMl}>30 \mathrm{~kg} \cdot \mathrm{m}^{-2}$ undergoing cesarean sections. This data

Received from Faculdade de Ciência Médicas da Universidade Estadual de Campinas Unicamp, Brazil.

1. Anesthesiologist of Hospital das Clínicas da Unicamp. Physician of Hospital das Clínicas da Unicamp

2. Professor of Faculdade de Ciência Médicas da Unicamp

Submitted on January 12, 2009.

Approved on July 25, 2010.

Correspondence to:

Dra. Maria José Nascimento Brandão

Rua Shigeo Mori, 1370

Cidade Universitária

13083-765 - Campinas, SP, Brazil

E-mail: mjnbceu@fcm.unicamp.br
Table I - Classification of Obesity According to the WHO

\begin{tabular}{lll}
\hline Classification & $\mathrm{BMI}\left(\mathrm{kg} \cdot \mathrm{m}^{-2}\right)$ & Risk of comorbidities \\
\hline Normal & $18.5-24.9$ & Medium \\
Overweight & $\geq 25$ & \\
Pre-obese & $25-29.9$ & Increased \\
Obese class 1 & $30-34.9$ & Moderate \\
Obese class 2 & $35-39.9$ & Severe \\
Obese class 3 & $\geq 40$ & Very severe \\
\hline
\end{tabular}

assessment intends to support the development of new protocols and conducts more adequate for this population of pregnant patients.

\section{METHODS}

This study was approved by the Ethics Committee for Research of Faculdade de Ciências Médicas of UNICAMP and was conducted according to ethical rules of research involving humans established by Resolution 196/96 of the National Health Council. This study was financed by the investigators.

This is a descriptive, retrospective study on anesthetic techniques used in cesarean sections in obese pregnant women undertaken at the Obstetric Center of CAISM/UNICAMP from January 2004 to December 2006. It included anesthetic forms of the Anesthesiology Service of CAISM referring to charts pregnants (BMI $\geq 30 \mathrm{~kg} \cdot \mathrm{m}^{-2}$ ) older than 18 year of age who underwent cesarean section under spinal anesthesia, except for cesarean section performed after labor analgesia. Incomplete or illegible anesthetic files were not included. Variables evaluated included age, weight, height, BMI, physical status (ASA), anesthetic techniques, difficulty in spinal puncture, 
hemodynamic complications (bleeding and hypotension), and anesthetic complications. The Spearman and Pearson tests were used to evaluate correlation. The Kruskal-Wallis test was used to compare continuous variables. A $p<0.05$ was considered statistically significant.

\section{RESULTS}

Three hundred and fifteen anesthetic files that fulfilled the inclusion criteria were evaluated. Table II shows the mean age and anthropometric data of the patients.

Patients were classified as ASA I, II, III, and IV (Table III). Out of 315 files evaluated, the presence of prior hypertension was reported by 143 patients $(45.4 \%)$, diabetes by 52 patients $(16.5 \%)$, deep venous thrombosis by two patients $(0.6 \%)$, and dyslipidemia by one patient $(0.3 \%)$. The majority of patients $(91.1 \%)$ underwent elective cesarean section. Twenty-eight (8.9\%) procedures were emergency cesarean sections, and in most of those cases, patients were classified as ASA II and III (10 and 11 cases, respectively); only one emergency procedure was performed in a patient classified as ASA IV.

As can be seen in Table III, the majority of patients had $\mathrm{BMI}>35$.

When mean surgical time was related to the body mass index, it was greater the higher the degree of obesity, with statistically significant differences $(p=0.04)$, (Table IV).

Spinal anesthesia was the anesthetic technique used more often $(62.2 \%)$, but other techniques such as single and continuous epidural, combined, and general anesthesia were also reported (Table V). General anesthesias performed total blo-

Table II - Age and Anthropometric Data

\begin{tabular}{llllll}
\hline & Minimal & Maximal & Median & Mean & $\mathrm{N}$ \\
\hline Age & 18 & 39 & 29 & 29.1 & 315 \\
Weight & 67 & 164 & 100 & 100 & 315 \\
Height & 1.32 & 1.80 & 1.60 & 1.60 & 315 \\
BMI & 30.80 & 60.24 & 38.79 & 39.25 & 315 \\
\hline
\end{tabular}

Table III - Physical Status (ASA) and Classification of Obesity

\begin{tabular}{ll}
\hline & Frequency \\
\hline Physical status & \\
ASA I & $50(15.9)^{\star}$ \\
ASA II & $199(63.2)$ \\
ASA III & $64(20.3)$ \\
ASA IV & $2(0.6)$ \\
Total & $315(100)$ \\
Obesity & \\
Class 1 & $64(20.3)$ \\
Class 2 & $127(40.3)$ \\
Class 3 & $124(39.4)$ \\
Total & $315(100)$ \\
\hline
\end{tabular}

${ }^{*} \mathrm{n}^{\circ}$ patients $(\%)$. ckade failure in one of the cases, and termination before the procedure ending in another case.

Technical difficulties regarding the anesthetic procedure were also observed. In 47 patients, it was difficult to palpate the interspinous spaces. Lumbar puncture was difficult in 31 patients, and those difficulties were directly related to the degree of obesity (Table VI). Difficulty in catheter progression in the epidural space was reported in two patients, one class 1 and the other class 2, who underwent continuous epidural anesthesia.

Mean volume of bleeding estimated during the cesarean section was $673 \mathrm{~mL}$, ranging from 150 to $1,500 \mathrm{~mL}$; the amount of bleeding was greater than the higher the classification of obesity without statistically significant differences $(p=0.52)$.

Complications observed during the cesarean section included one case of hypoxia ( $0.3 \%)$, and 79 cases of hypotension (25.1\%). Table VII shows the correlation between hypotension and class of obesity. Bronchospasm was not reported.

The need to complement anesthesia was greater in obesity classes 2 and 3 . As for blockade failure, statistically significant differences were not observed among the classes of obesity, as demonstrated in Table VIII. One case of complete failure and one of termination of the blockade before the end of the procedure were converted to general anesthesia. Four cases $(1.3 \%)$ of puncture of the dura mater, in which one of the cases had complete spinal anesthesia that required tracheal intubation, were reported.

Table IV - Mean Surgical Time According to the Class of Obesity

\begin{tabular}{ll}
\hline Class of obesity & Mean surgical time (minutes) \\
\hline 1 & $81.25 \pm 18.02$ \\
2 & $83.78 \pm 21.18$ \\
3 & $88.02 \pm 22.94$ \\
\hline
\end{tabular}

$p=0.0076$

Table V - Anesthetic Techniques

\begin{tabular}{ll}
\hline & Frequency \\
\hline Spinal anesthesia & $196(62.2)^{\star}$ \\
Single epidural & $58(18.4)$ \\
Continuous epidural & $48(15.2)$ \\
Combined & $11(3.5)$ \\
General & $2(0.6)$ \\
Total & $315(100)$ \\
\hline
\end{tabular}

${ }^{*} \mathrm{n}^{\circ}$ patients $(\%)$.

Table VI - Technical Difficulties According to Class of Obesity

\begin{tabular}{lllll}
\hline \multicolumn{5}{l}{ Type of technical difficulty } \\
\hline BMI & Without difficulty & Palpation & Puncture & Total \\
30 a 34.99 & 57 & 5 & 1 & 63 \\
35 a 39.99 & 96 & 15 & 15 & 126 \\
$>$ 40 & 81 & 27 & 15 & 123 \\
Total & 234 & 47 & 31 & 312
\end{tabular}

$\mathrm{p}=0.0028$. 
Table VII - Bleeding and Hypotension According to the Class of Obesity

\begin{tabular}{lll}
\hline & Bleeding & Hypotension \\
\hline Class 1 & $9(19.6)^{*}$ & $15(18.8)$ \\
Class 2 & $16(34.8)$ & $26(32.5)$ \\
Class 3 & $21(45.6)$ & $39(48.7)$ \\
Total & $46(100)$ & $80(100)$ \\
\hline
\end{tabular}

${ }^{*} \mathrm{n}$ - patients $(\%)$.

Table VIII - Blockade Failure Regarding the Degree of Obesity

\begin{tabular}{llll}
\hline & Class 1 & Class 2 & Class 3 \\
\hline Without & $63(98.4)^{\star}$ & $123(96.9)$ & $119(96.7)$ \\
Partial & $1(1.6)$ & $2(1.6)$ & $3(2.4)$ \\
Total & $0(0)$ & $2(1.6)$ & $1(0.8)$ \\
\hline
\end{tabular}

* $\mathrm{n}$ - patients (\%).

\section{DISCUSSION}

Physiologic changes of pregnancy associated to changes caused by obesity lead obese pregnant women to have limited physiologic reserves. Supine position represents a cardiovascular and respiratory risk due to changes in lung volumes and capacities, changes in ventilation/perfusion ratio, and aorta-cava compression. The cephalad retraction of the adipose tissue leads to maternal respiratory difficulties and it can also worsen hypotension. Spinal anesthesia is the most common type of anesthesia used in cesarean sections ${ }^{7}$. It causes a more dense and reliable blockade and fast onset; however, technical difficulties do exist, such as the potential for a higher blockade of the thoracic musculature leading to respiratory difficulties and impossibility of complementing the anesthesia in case the surgery is prolonged ${ }^{8}$. In our study, spinal anesthesia was the technique used more often, which is in agreement with reports in the literature. In our data, we did not find reports of respiratory difficulties and no patient presented hypoxia.

The epidural space in pregnant women might be reduced due to engorgement of veins in the extra-dural space, compression of the subarachnoid space, and reduction in the volume of cerebrospinal fluid. Engorgement of veins in the extra-dural space and increased pressure are secondary to the increased intra-abdominal pressure, which causes compression of the inferior vena cava and consequent reduction in the volume of cerebrospinal fluid. Thus, it is more difficult to predict the extension of the blockade when using the same dose of local anesthetics in obese and non-obese pregnants. Besides, it is known that the need of local anesthetic in spinal anesthesia is lower in pregnants especially obese. Mechanisms suggested for this include pregnancyspecific hormonal changes, which affect the action of neurotransmitters in the spinal column, increased permeability of neural membranes, and other pharmacokinetic and pharmacodynamic changes ${ }^{8,9}$. Epidural anesthesia is an alternative to spinal anesthesia; its advantages include titration of the dose of local anesthetics with better control of hemodynamic changes, possibility of complementation in cases of prolonged surgical time (use of continuous epidural anesthesia), and use of a catheter for postoperative analgesia. In the present study, the higher percentage of hypotension was observed in pregnant women with obesity class 3 , which might be due to greater extension of a higher sympathetic blockade caused by compression of the subarachnoid space by the pregnant abdomen associated with obesity ${ }^{8}$.

Spinal anesthesia can be technically complicated in obese pregnant women because of the posture, difficulty in localizing the midline, and loss of anatomic references ${ }^{10,11}$. The midline can be located by the prominence of $\mathrm{C} 7$ and the intergluteal cleft. Studies have suggested the cooperation of the patient to locate the midline or even the use of the ultrasound to locate the epidural space ${ }^{12}$, which is not routine in our service. Those difficulties are more pronounced the higher the BMI, which was observed in the data obtained where a higher percentage of difficulty palpating the intervertebral spaces and lumbar puncture was observed in pregnant women with class 3 obesity ${ }^{8}$, seen in eight cases. The literature suggests the use of the paramedian approach ${ }^{8}$, which was done in eight cases in the present study.

Difficulty of puncture, and in locating the midline and the epidural space are associated with a high rate of catheter migration and a consequent blockade failure, and complications like puncture of the dura mater 8,12 . This study was undertaken at a teaching hospital, which has a considerable number of residents and, for this reason, a high probability of termination of the blockade during the surgery exists. In two cases, anesthesia was complemented through the epidural catheter. In four cases, a new anesthesia was performed, and in two cases, it was converted to general anesthesia and one of those cases it was due to termination of the blockade.

The depth of the epidural space in relation to the skin is related to the BMI, but in only a small percentage of patients this space is greater than 8 centimeters ${ }^{13}$. According to Brockelsby, in a study that evaluated 14,000 obese pregnant women undergoing epidural anesthesia, only $2 \%$ required needles greater than $8 \mathrm{~cm}{ }^{14}$. In the present study, only one patient required a needle longer than $8 \mathrm{~cm}$; in the remaining patients, blockades were performed with standard needles.

The estimated surgical time for non-obese pregnants in the literature is around 60 minutes. It seems logical to imagine that in obese pregnants this time increases, and this could be observed in our data. We observed that not only the surgical time was greater than 60 minutes, but it also increases as the $\mathrm{BMI}$ increases. Thus, we can also imagine that the estimated blood loss will be greater the higher the BMI ${ }^{9}$, which was also observed; the blood loss was greater in the group of pregnant women with class 3 obesity.

Since obesity is a public health problem, the probability of encountering this type of patient increases, which leads to the conclusion that anesthesiologists should be more prepared to handle those patients, being familiar with the implications of obesity, performing evaluations, if possible during the prenatal period, establishing a follow-up protocol along with the 
multidisciplinary team to minimize technical difficulties and, especially, the maternal-fetal risks during labor.

Since this was a retrospective study of data gathering from anesthetic files, some data might have been lost, which would create a bias in the analysis of the results.
From our data, one can observe that spinal anesthesia was used more often, which is in agreement with the literature. Besides, it was observed that the higher the BMI, the greater the technical difficulties, bleeding, percentage of hypotension, and surgical time. 
08. Saravanakumar K, Rao SG, Cooper GM - Obesity and obstetric anaesthesia. Anaethesia, 2006;61:36-48.

09. Andreasen KR, Andersen ML, Schantz AL - Obesity and pregnancy. Acta Obstet Gynecol Scand, 2004;83:1022-1029.

10. Hood DD, Dewan DM - Anesthetic and obstetric outcome in morbidly obese parturients. Anesthesiology, 1993;79:1210-1218

11. Perlow JH, Morgan MA - Massive maternal obesity and perioperative cesarean morbidity. Am J Obstet Gynecol, 1994;170: 560-565.

12. Bongain A, Isnard V, Gillet JY - Obesity in obstetrics and gynaecology. Eur J Obstet Gynecol Reprod Biol, 1998;77:217-228.

13. Guasch E, Ortega R, Gilsanz F - Analgesia epidural para parto em la gestante obesa. Rev Soc Esp Dolor, 2006;13:468-474.

14. Brockelsby J, Dresner M - Obesity and pregnancy. Curr Anaesth Crit Care, 2006;17:125-129.

Resumen: Rodrigues FR, Brandão MJN - Anestesia Regional para Cesárea en Embarazadas Obesas: Estudio Retrospectivo.

Justificativa y objetivos: La investigación de los datos tuvo el objetivo de identificar las técnicas anestésicas, sus dificultades y complicaciones en pacientes con IMC > = $30 \mathrm{~kg} \cdot \mathrm{m}-2$, sometidas a la cesárea. Esa investigación se justifica porque tiene como base el desarrollo de nuevos protocolos y de conductas más adecuadas para esa población de embarazadas.

Método: Estudio retrospectivo de investigación de datos y complicaciones anestésicas en pacientes obesas, mayores de 18 años y sometidas a la cesárea durante el período de enero de 2004 a diciembre de 2006. Las variables evaluadas fueron: edad, peso, altura, IMC, estado físico (ASA), técnicas anestésicas, dificultades en la palpación y punción, complicaciones hemodinámicas (sangramiento e hipotensión) y complicaciones anestésicas.

Resultados: Se evaluaron 315 fichas anestésicas. El promedio de edad fue de 29,1 años, el IMC promedio fue de 39,25 y la mayoría de las pacientes se clasificaron como ASA II (63,2\%). La técnica anestésica más utilizada fue la raquianestesia. En 47 procedimientos se registró la dificultad de punción y en 31 casos dificultad de palpación.

Conclusiones: Las dificultades técnicas encontradas fueron más profundas en pacientes con clase más alta de obesidad, como también hipotensión, sangramiento y tiempo de quirófano.

Descriptores: ANESTESIA, Obstétrica; CIRUGÍA, Obstétrica: cesárea; ENFERMIDAD,Obesidad: mórbida; TÉCNICAS ANESTÉSICAS, Regional:peridural, raquianestesia.. 